\title{
IDENTIFIKASI DNA Leptospira sp PADA SAMPEL AIR DAN TANAH DI KOTA MAKASSAR
}

\author{
Muhammad Fadhlullah Mursalim¹, Mochammad Hatta² \\ ${ }^{1}$ Program Studi Kedokteran Hewan Fakultas Kedokteran Universitas Hasanuddin \\ ${ }^{2}$ Bagian Mikrobiologi, Fakultas Kedokteran, Universitas Hasanuddin \\ Email:dullahmursalim@gmail.com
}

\begin{abstract}
Leptospirosis is a zoonotic disease that can be found all over the world, caused by a pathogenic leptospira genus. This study aims to identify the presence of Leptospira bacterial DNA in water and soil at several locations in Makassar. This research was conducted in microbiology laboratory Faculty of Medicine Hasanuddin University. A total of 16 samples were taken consisting of water and soil samples taken from four locations in Makassar City namely eggplant market, slums, TPA (final landfill) tamangappa and slaughterhouse (RPH). Samples were then tested using the nested RT-PCR method. The results of this study showed that from 16 samples tested showed one sample with positive to the presence of Leptospira sp bacteria obtained from the soil found in slums located in makassar.
\end{abstract}

Key words: Leptospirosis, leptospira, water, soil, nested RT-PCR

\section{PENDAHULUAN}

Leptospirosis merupakan penyakit zoonosis yang tersebar hampir di seluruh dunia, disebabkan oleh infeksi bakteri yang berbentuk spiral dari genus Leptospir. ${ }^{1}$ Leptospira masuk ke dalarn tubuh melalui kulit yang terluka atau membran mukosa. Bakteri Leptospira masuk ke dalam tubuh manusia dapat melalui kulit yang lecet/ luka, selaput lendir (mukosa) mata, hidung dan kadang-kadang melui saluran cerna dari makanan yang terkontaminasi oleh urin tikus atau mamalia lain yang terinfeksi oleh kuman Leptospira. ${ }^{2}$

Pekerjaan merupakan faktor resiko yang penting pada manusia. Kelompok yang beresiko adalah petani atau pekerja di sawah, perkebunan tebu, tambang, rumah potong hewan, perawat hewan, dokter hewan atau orang-orang yang berhubungan dengan perairan, lumpur dan hewan baik hewan peliharaan ataupun satwa liar. ${ }^{3}$ 
Selain itu, Leptospirosis juga beresiko terhadap individu yang terpapar air yang terkontaminasi. Di daerah endemis, puncak kejadian Leptospirosis terutama terjadi pada saat musim hujan dan banjir. Iklim yang sesuai untuk perkembangan Leptospira adalah udara yang hangat, tanah yang basah dan $\mathrm{pH}$ alkalis, kondisi ini banyak ditemukan di negara beriklim tropis.

Oleh sebab itu penyakit ini paling sering ditemukan di negaranegara tropis atau subtropis baik di perkotaan maupun pedesaan. Kejadian setiap tahun diperkirakan 0,1-1 per 100.000 di daerah beriklim sedang dan untuk daerah tropis lembab diperkirakan 10-100 per 100.000. Kejadian penyakit lebih dari 100 per 100.000 pernah ditemui selama wabah dan pada kelompok yang berisiko tinggi. ${ }^{4}$

Leptospirosis merupakan penyakit yang dapat ditularkan melalui air. ${ }^{5}$ Urin dari individu yang terserang penyakit ini merupakan sumber utama penularan, baik pada manusia maupun pada hewan. Tikus dan mamalia, seperti sapi, babi dan anjing, berfungsi sebagai reservoir hosts utama. Hewan yang terinfeksi dapat mengeluarkan Leptospira selama berbulan-bulan atau bertahun-tahun, atau seumur hidup mereka. Hewan yang divaksinasi mungkin masih mengeluarkan organisme infeksi dalam urin.

Leptospirosis di Indonesia pada tahun 2005-2011 tersebar di DKI Jakarta, Jawa Barat (Kota Bandung), Jawa Tengah (Demak, Purworejo, Klaten, Kabupaten/Kota Semarang, Pati), DIY, Jawa Timur (Ponorogo, Gresik, Malang), Bengkulu (Kab. Kaur), Kepulauan Riau (Tanjung Uban), Sulawesi Selatan (Makassar, Gowa, Maros, Pinrang). Data dari Dinas Kesehatan Provinsi Jawa Tengah tahun 2004-2011 terdapat beberapa Kabupaten/Kota yang merupakan daerah dengan masalah ${ }^{5}$ leptospirosis yaitu Kota Semarang, Kabupaten Semarang, Demak, Klaten, Pati, Purworejo, Jepara, Wonogiri, Sukoharjo, Cilacap serta Banyumas, Purbalingga, dan Banjarnegara. ${ }^{6}$

Ada beberapa pemeriksaan yang umum dilakukan untuk mendiagnosis penyakit leptospirosis diantaranya Microscopic Agglutination Test (MAT) sebagai gold standard, Enzyme-Linked Immunosorbent Assays (ELISA), dan Immunochromatographic Test (ICT), PCR, IHA, dan lain-lain. Untuk deteksi Leptospira, uji PCR cukup sensitif dan spesifik, serta hanya memerlukan 
waktu yang singkat, sehingga hasil yang diperoleh sangat cepat. Karena itu, teknik PCR cukup baik dipakai untuk diagnosis penyakit leptospirosis maupun untuk identifikasi DNA bakteri Leptospira. ${ }^{7}$ Berdasarkan uraian di atas penelitian ini bertujuan untuk memeriksa potensi peran air dan tanah di persistensi dan penyebaran Leptospira di kota Makassar. Sampel air dan tanah dikumpulkan kemudian diperiksa keberadaan DNA Leptospira dengan Nested-PCR.

\section{METODE PENELITIAN}

Penelitian ini dilakukan di laboratorium Mikrobiologi Fakultas Kedokteran Universitas Hasanuddin Makassar. Sampel air dan tanah diambil dari 4 lokasi di Kota Makassar yaitu di Pasar Terong, Daerah Kumuh, TPA Tamangapa dan Rumah Potong Hewan kota Makassar . Untuk pengambilan sampel dilakukan selama 1 minggu dengan pengambilan sampel secara bertahap dan di tiap lokasi yang berbeda. JumLah sampel terdiri atas 16 diantaranya 2 sampel air dan 2 sampel tanah pada 4 lokasi yang berbeda. Bahan yang digunakan dalam penelitian antara lain DW steril, L6 (Lysis buffer), silica, $\mathrm{NaOH}, \mathrm{L} 2$ (Washing buffer), etanol, aseton, Reagen PCR, Agar rose, ultra pare, dan iodin. Sampel yang telah diperoleh diekstraksi terlebih dahulu, pada sampel tanah direndamkam dengan larutan DW steril untuk diencerkan serta menguraikan DNA unsur tanah sedangkan pada sampel air tidak di encerkan. Sampel kemudian di memasukkan ke dalam tube lalu diberikan label di setiap sampelnya. Fragmen gen lipoprotein LipL32 digunakan sebagai marker genetik untuk mendeteksi DNA Leptospira spp. Identifikasi menggukanan beberapa primer yaitu Amu1 (5'- CGC GCT GCA GTT ACT TAG TCG CGT CAG AAG-3') and Amu2 (5'- CGC GGT CGA CGC TTT CGG TGG TCT GCCAAG c-3') untuk amplifikasi fragmen gen lipoprotein LipL32. Untuk metode reaksi semi-nested PCR, primer yang digunakan yaitu Amu2 and AmuN (5'-CTA TGT TTG GAT TCC TGC-3'). ${ }^{8}$

Setelah pengambilan sampel dilanjutkan dengan prosedur isolasi DNA/RNA Boom dengan cara mix tiap tube. Tiap sampel di masukkan ke dalam cup sebanyak $50 \mu L$ kemudian disentrifus dengan kecepatan 13.000 rpm selama 5 menit. Setelah itu DNA tiap sampel mengendap di bawah cup kemudian menambahkan cairan L6 (lisis buffer) lalu di vortex selama 1-2 menit. Semua cairan di tiap sampel 
dibuang dengan hanya menyisakan endapan diatomnya saja. ${ }^{9}$

Diatom kemudian dicuci dengan cairan L2 lalu vortex dan disentrifus selama 15 detik. Pencucian dilanjutkan dengan menggunakan etanol $70 \%$ sebanyak 2 kali dan masing masing pencucian disentrifus selama 15 detik dengan kecepatan 13.000 rpm. Setelah itu dilakukan proses pengeringan dengan menggunakan aseton lalu disentrifus selama 15 detik dan dilanjutkan dengan menggunakan heating block dengan suhu $54^{\circ} \mathrm{C}$ selama 20-30 menit hingga kering seperti bubuk. $^{9}$

Setelah proses tersebut dilanjutkan dengan proses elusi dengan cara menambahkan $50 \mu \mathrm{L}$ buffer Tris-EDTA ke dalam tube sampel lalu dicampur dan diinkubasi selama 10 menit pada suhu $54^{\circ} \mathrm{C}$ dalam heating block. Setelah itu disentrifus selama 2 menit dengan kecepatan 13.000 rpm kemudian ambil supernatannya sebanyak $40 \mu L$ untuk dipindahkan ke dalam vial $0,5 \mathrm{~mL}$, hindari terambilnya endapan pada sampel lalu simpan ekstrak sampel tersebut pada suhu $-20^{\circ} \mathrm{C} .{ }^{9}$

Hasil isolasi sampel kemudian dilakukan prosedur nested RT-PCR dengan cara mempersiapkan larutan PCR mix untuk masing-masing sampel dengan komposisi dNTP $0,1 \mathrm{~mL}, 10 \mathrm{x}$ buffer 2,5 $\mu \mathrm{L}$, primer forward $1 \mu \mathrm{L}$, primer reverse $1 \mu L, \mathrm{MgCl}_{2} 0,5 \mu \mathrm{L}, \mathrm{H}_{2} \mathrm{O}$ $14 \mu \mathrm{L}$, dan Taq polymerase $0,1 \mu \mathrm{L}$ Ialu dicampurkan dengan sampel $5 \mu L$ serta dicover dengan minyak paraffin untuk mencegah terjadinya penguapan selama siklus PCR. Setelah itu dilakukan proses siklus PCR dengan suhu $94{ }^{\circ} \mathrm{C}$ selama 3 menit dan dilanjutkan dengan $35 \mathrm{x}$ siklus siklus PCR dengan siklus pertama terdiri dari $94^{\circ} \mathrm{C}$ selama 30 detik, $72{ }^{\circ} \mathrm{C}$ selama 60 detik dan $72{ }^{\circ} \mathrm{C}$ selama 7 menit . Kemudian dilanjutkan siklus PCR kedua dengan larutan PCR mix yang sama komposisinya dan sampel yang digunakan adalah sampel dari hasil siklus PCR sebelumnya lalu diproses dengan siklus PCR dengan suhu 94 ${ }^{\circ} \mathrm{C}$ selama 3 menit dan dilanjutkan dengan $35 x$ siklus dengan satu siklus terdiri dari $94{ }^{\circ} \mathrm{C}$ selama 30 detik, 58 ${ }^{\circ} \mathrm{C}$ selama 30 detik, $72{ }^{\circ} \mathrm{C}$ selama 60 detik dan $72^{\circ} \mathrm{C}$ selama 7 menit.

Pembuatan agar rose sebanyak $2 \%$ ditambahkan air sebanyak $40 \mathrm{~mL}$ kemudian pengenceran dengan ultra pare sebanyak $40 \mathrm{~mL}$. Di didihkan untuk pembekuan kemudian dimasukkan ke dalam micro wafe selama 1 menit lalu dikocok agar mendidih dan di ulang selama 30 
detik. Kemudian dicetak dengan pencetak elektroforesis dimana menggunakan water pass. Agar rose ditambahkan dengan ethidium bromide sebanyak $2 \mu \mathrm{L}$ setelah itu diamkan selama 30 menit hingga konsistensi agar menjadi padat. Sisir cetakan kemuadian diangkat sehingga pada agar terbentuk lubang kecil. DNA iodin /pewarna diambil sebanyak $1 \mu L$ yang akan dicampurkan pada tiap sampel, kemudian di masukkan ke dalam lubang yang terbentuk pada media agar dan melakukan elektroforesis serta pembacaan hasil. Hasil negatif apabila tidak ditemukan, tidak ada terbentuk bar pada baris sampel yang sudah diuji akan tetapi bila positif maka akan terbentuk bar pada baris sampel yang dimasukkan ke dalam well. $8,10,11$

\section{HASIL PENELITIAN DAN PEMBAHASAN}

Berdasarkan hasil penelitian dari 16 sampel air dan tanah Setelah dilakukan siklus PCR, sampel tersebut kemudian dibaca melalui proses eletroforesis yang menghasilkan temuan positif pada satu sampel yaitu sampel tanah yang diperoleh pada salah satu lokasi yaitu di daerah kumuh. Hasil yang diperoleh dari proses elektroforesis yang diamati melalui UV transluminator yaitu positif atau terdeteksinya bakteri leptospira pada satu sampel yaitu tanah yang berlokasi di daerah kumuh di Kota Makassar. Hasil nested-PCR bisa dilihat pada Tabel 1.

Tabel 1. Positif Leptospira pada sampel air dan tanah yang ditemukan di berbagai lokasi

\begin{tabular}{ccc}
\hline Sumber sampel & Air positif/diperiksa (\%) & Tanah positif /diperiksa (\%) \\
\hline Pasar Terong & $0 / 2$ & $0 / 2$ \\
Daerah Kumuh & $0 / 2$ & $1 / 2$ \\
TPA Tamangapa & $0 / 2$ & $0 / 2$ \\
RPH Makassar & $0 / 2$ & $0 / 2$ \\
\hline Total & $\mathbf{0 / 8}$ & $\mathbf{1 / 8}$ \\
\hline
\end{tabular}

$\begin{array}{llll}\text { Kondisi sanitasi yang buruk } & \text { keberadaan tikus merupakan variabel } \\ \text { pada daerah kumuh seperti } & \text { penentu kasus leptospirosis. } \\ \text { keberadaan timbunan sampah, } & \text { Penularan leptospirosis oleh bakteri } \\ \text { banyaknya genangan banjir dan } & \text { Leptospira bisa melalui kontak }\end{array}$


langsung dengan urin dan cairan tubuh hewan yang terinfeksi atau kontak tidak langsung melalui air atau tanah yang terkontaminasi oleh bakteri Leptospira. ${ }^{1}$ Rendahnya persentase sampel air yang mengandung DNA Leptospira sama dengan hasil yang didapatkan $^{8}$, yang melakukan penelitian serupa yang berlokasi di Polandia ${ }^{11}$ melakukan pemeriksaan menggunakan qPCR untuk mengetahui bakteri Leptospira yang dilakukan pada 368 sampel berhasil dikumpulkan.

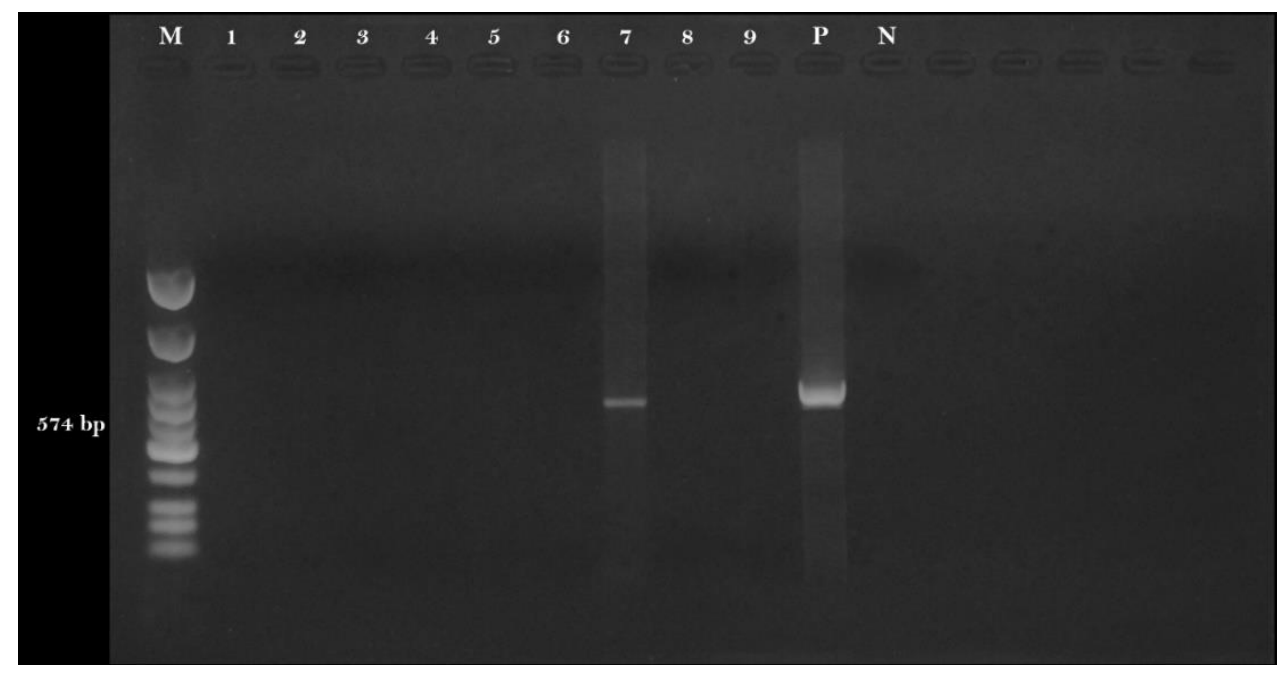

Gambar 1. Hasil pembacaan elektroforesis pada sampel tanah

Hasil penelitian diperoleh 140 sampel positif patogen Leptospira, yang terdiri dari $25(25,25 \%)$ sampel tikus, 51 (42,86\%) sampel air dan 64 $(42,67 \%)$ sampel tanah. Berdasarkan lokasi sampel yang dikumpulkan, Kecamatan Bantul merupakan daerah dengan Leptospira positif tertinggi sebesar $51,68 \%$ disusul oleh Kecamatan Sewon dan Sedayu masing $32,32 \%$ dan $25,83 \%$. Pada kesimpulannya, hasil ini menunjukkan bahwa sampel air dan tanah memiliki keterbatasan yang signifikan dalam penyebaran dan terus menerus oleh bakteri Leptospira

\section{KESIMPULAN}

Berdasarkan hasil penelitian identifikasi dna leptospira sp pada sampel air dan tanah di beberapa lokasi kota makassar maka disimupulkan bahwa terdapat 1 sampel tanah yang positif. Sampel diperoleh dari daerah kumuh di sekitaran pasar terong. 


\section{DAFTAR PUSTAKA}

1. Kusmiyati, Noor SM, Supar. Animal and human Leptospirosis in Indonesia. Wartazoa. 2005;15(4):213-9.

2. Rejeki DSS, Nurlaela S, Octaviana D. Pemetaan dan Analisis Faktor Risiko Leptospirosis. Kesmas J Kesehat Masy Nas [Internet]. 2013;0(0):179.

3. Susanti K dan S. Seroprevalensi Dinamik Leptospirosis Pada Daerah Pengembangan Sapi Perah. Science (80- ). 2007;372-7.

4. Victoriano AFB, Smythe LD, Gloriani-Barzaga N, Cavinta LL, Kasai T, Limpakarnjanarat $\mathrm{K}$, et al. Leptospirosis in the Asia Pacific region. BMC Infect Dis [Internet]. 2009;9(1):147. 23349-147

5. Cann KF, Thomas DR, Salmon $R L$, Wyn-Jones AP, Kay D. Extreme water-related weather events and waterborne disease. Epidemiol Infect. 2013;141(4):671-86.

6. Yuliadi B, Wahyuni, Ristianto. Distribusi Spasial Leptospirosis di Wilayah Provinsi Jawa Tengah Tahun 2002-2012. J Vektora. 2013;V(2):66-72.

7. Ramadhani T, Widyastuti D, Priyantol D. Determinasi Serovar
Bakteri Leptospira Pada

Reservoir Di Kabupaten

Banyumas Determination of Leptospira Serovar in Reservoir in Banyumas District. J Ekol Kesehat. 2015;14(1):8-16.

8. Wójcik-Fatla A, Zajac V, Wasinski B, Sroka J, Cisak E, Sawczyn A, et al. Occurrence of Leptospira DNA in water and soil samples collected in eastern Poland. Ann Agric Environ Med. 2014;21(4):730-2.

9. Pada M, Mycobacterium I, Bali DI. MENGGUNAKAN DUA METODE BOOM MODIFIKASI PADA ISOL .... 2016;(January 2014).

10. Nassi F, Seixas FK, Dorneles Jouglard SD, Simionatto S, Silva $E F$, Seyffert $N$, et al. Leptospirosis diagnosis using nested-PCR. Brazilian J Microbiol. 2003;34(SUPPL. 1):90-2.

11. Sumanta $H$, Wibawa $T$, Hadisusanto S, Nuryati A, Kusnanto H. Spatial Analysis of \&amp;It;i\&amp;gt;Leptospira\&am p;lt;/i\&amp;gt; in Rats, Water and Soil in Bantul District Yogyakarta Indonesia. Open $\mathrm{J}$ Epidemiol [Internet]. 2015;5(1):22-31. Available from: http://www.scirp.org/journal/doi.a spx?DOI=10.4236/ojepi.2015.51 004 